\title{
THE EFFECT OF SOIL MULCHING ON THE YIELDING OF HARDY KIWIFRUIT CULTIVARS (Actinidia arguta) IN CENTRAL POLAND
}

\section{WPŁYW ŚCIÓŁKOWANIA GLEBY NA PLONOWANIE ODMIAN AKTINIDII OSTROLISTNEJ (Actinidia arguta) W CENTRALNEJ POLSCE}

\author{
Research Institute of Horticulture, Skierniewice, Poland
}

\begin{abstract}
Streszczenie. Minikiwi (Actinidia arguta) jest nową rośliną sadowniczą polecaną do uprawy w Polsce. Istnieje wiele możliwości zakładania sadów $z$ tego gatunku, ale największym problemem jest wrażliwość aktinidii na późne wiosenne przymrozki. Latem w tracie suszy wymagane jest także nawadnianie plantacji. W przeprowadzonym doświadczeniu badano efekt ściółkowania gleby słomą na plonowanie 5 odmian minikiwi. Plantację doświadczalną założono w 2005 roku, ale obserwacje plonowania prowadzono w latach 2010-2015, kiedy krzewy weszły w pełnię owocowania. Połowę rzędu z każdą odmianą ściółkowano słomą, a połowa utrzymywana była w postaci ugoru herbicydowego. Rośliny nie były dodatkowo nawadnianie latem. Plonowanie odmian aktinidii było bardzo zróżnicowane, ale wyniki wskazują, iż ściółkowanie gleby poprawiło plonowanie wszystkich odmian. Największy plon handlowy uzyskano z odmian ściółkowanych 'Ananasnaya', 'Geneva' i 'Weiki'. Ogólnie plon handlowy z roślin ściółkowanych słomą był większy (0,83-1,98 kg na roślinę) niż plon odmian uprawianych na ugorze herbicydowym.
\end{abstract}

Słowa kluczowe: aktinidia, minikiwi, ściółkowanie gleby, pnącza owocowe.

Key words: fruit climbers, hardykiwi, kiwiberry, soil mulching.

\section{INTRODUCTION}

New fruit-producing horticultural plants are still needed so that agricultural diversity may increase. Growing hardy kiwifruit (Actinidia arguta (Siebold at Zucc.) Planch. ex Miq.) has also become more popular in Poland (Latocha and Krupa 2007; Marosz 2009, 2016). According to plant anatomy and morphology, the kiwiberry plant requires an appropriate support structure. The fruit of this species is very nutritional and contains rich sources of easily absorbed vitamin C (Williams et al. 2003; Latocha 2017). Growing this plant commercially does not pose any major problems (Chesoniene 2000; Bieniek 2012). Cultivars of hardy kiwi offered on the market and recommended for orchards, are frost resistance and can be grown in many region of Poland (Marosz 2009; Bieniek 2012; Latocha 2012). For good annual yielding, plants need to be protected before late spring frosts and should be watered during summer droughts. Orchards with hardy kiwi should be equipped with overhead sprinkling irrigation, be protected from spring frost, and be provided with a capillary

Corresponding author - Adres do korespondencji: Adam Marosz, Research Institute of Horticulture, Konstytucji 3 Maja 1/3, 96-100 Skierniewice, Poland, e-mail: adam.marosz@wp.pl 
watering system for summer irrigation as well. In addition to these important investments, it should be noted that the building structure support as well as the fencing for the orchard, are also very expensive. That is why, total basic investment costs including the plant material, reached in Poland over 41000 PLN per hectare (Marosz 2016).

When developing or expanding a farm, it is important to seek ways to lower production costs without having a negative effect on the yield. Mulch covering of the soil in the orchard is an example of one way to lower the costs. Some authors reported that mulching generally improves the root and shoot growth of plants (Harris et al. 2004). Mulching improved the vegetative growth of apple trees in orchards (Szewczuk et al. 2011; Kotze 2015), had a positive impact on the assimilation of some strawberry plant macroelements (Kęsik and Maskaleniec 2004), and positively affected the yielding of lingonberries (Laszlovszky Zmarlicka 2015). Mulches positively affected the $\mathrm{pH}$ and organic matter content of soil in the experiment with apple cv. 'Gold Millennium' (Sas-Paszt et al. 2012). In ornamentals mulching significantly promoted growth of red horsechestnut and european linden without significantly affecting tree physiology (Ferrini et al. 2008). Ornamental shrubs in containers grew better when mulching was provided. However, organic mulching materials like straw, had less of an effect on weed control and ornamental shrub growth than using coco-discs (Marosz 2012). Mulching can help save water when drip irrigation is used.

The aim of this field-conducted study was to evaluate how soil mulching affects the yielding of hardy kiwi when limited herbicide control is used, and when there is no additional summer watering.

\section{MATERIAL AND METHODS}

The study was conducted on the experimental field of the Institute of Horticulture in Skierniewice, Poland, during the 2010-2015 time period. The orchard, though, was started in 2005, and during the experiment, the plants were in full yield. Five cultivars of hardy kiwi: 'Ananasnaya', 'Geneva', 'Jumbo', 'Ken's Red', and 'Weiki' were planted in single rows with a $3.5 \mathrm{~m}$ space between the rows. The space between the plants in the rows was $2.2 \mathrm{~m}$. The sandy loam soil had a low amount of organic matter (the surface soil layer of $0-40 \mathrm{~cm}$ consisted of $69 \%$ sand, $15 \%$ silt, and $16 \%$ clay), the $\mathrm{pH}$ was 6.4 . The soil contained these macroelements: $\mathrm{mg} \cdot \mathrm{L}^{-1}$ : N-NO3, $\mathrm{P}, \mathrm{K}, \mathrm{Mg}, \mathrm{Ca}, 6,64,176,57,700$, respectively. Manure was added at $20 \mathrm{t}$ per hectare during the autumn before deep plowing. During the spring, before the plants were planted, mineral fertilisers were added to establish good growing conditions. The fertilisers contained dolomite, potassium sulphate, and triple superphosphate at $1.4,0.3$, and $0.2 \mathrm{t} \cdot \mathrm{ha}^{-1}$, respectively. Cultivars of hardy kiwi were planted in blocks where there were ten plants of every cultivar and one male plant needed as a pollinator ('Weiki' male). The support for the plants consisted of concrete posts with three lines of wire at heights of $40 \mathrm{~cm}, 110 \mathrm{~cm}$, and $170 \mathrm{~cm}$ from the ground. In total, 200 female plants of hardy kiwi and 20 male pollinators were planted in 4 rows. Male plants in the rows were mixed with the same pattern for the line 1 and 3 , and line 2 and 4 . Mixing male pollinators for the line one was as follow: 5 female, 1 male; 10 female, 1 male; 10 female, 1 male; 10 female, 1 male; 10 female, 1 male; and 5 female. The second line started from 1 female, 1 male and 
9 female than 1 male, 10 female; 1 male, 10 female; 1 male, 10 female; 9 female, 1 male and 1 female. Such arrangement of male plants was chosen to provide as best pollination of female flowers as possible. The rows were as long as $121 \mathrm{~m}$, with 55 plants. The mulch was straw from winter cereals. The mulch was spread the first time in early spring (end of March 2010), on clean soil, for the $11 \mathrm{~m}$ distance. Five of the plants in the block were included in the mulching. The other five plants in the block were maintained using herbicide (glyphosate $3 \mathrm{~L} \cdot \mathrm{ha}^{-1}$ ) and treated as the control. The herbicide and mulch zones were $120 \mathrm{~cm}$ wide. Inter-row turf was put in and then mowed 2-3 times a month. Mulching was done in early spring every year during the study. The plots were fertilised annually with YaraMila ${ }^{\mathrm{TM}}$ Complex fertiliser $20 \mathrm{~g} \cdot 1 \mathrm{~m}^{-1}$ which contains macro and microelements, $\mathrm{g} \cdot \mathrm{kg}^{-1}: \mathrm{N}-\mathrm{NO}_{3}$, $\mathrm{N}-\mathrm{NH}_{4}, \mathrm{P}_{2} \mathrm{O}_{5}, \mathrm{~K} 2 \mathrm{O}, \mathrm{MgO}, \mathrm{SO}_{3}, \mathrm{~B}, \mathrm{Fe}, \mathrm{Mn}, \mathrm{Zn}, 5,7,11,18,2.7,20,0.015,0.2,0.02,0.02$, respectively. During the experiment, weeds that appeared in the mulching zone were hand removed.

The METHOS Data System (Pessl Instruments Ltd. Weiz, Austria) was used to provide details on the general weather conditions, during each year. The System was placed nearly 600 meters away from the experiment. In the 2010 winter, there was a lot of frost, with temperatures as low as $-25^{\circ} \mathrm{C}$, but there was also thick snow cover. Precipitation during the spring and summer of 2010, was very intensive, which was good for plant growth. The winter of 2011 was mild, with stronger frosts and low snow cover in February. On May 3-4, however, a strong, late-spring frost occurred $\left(-5,2^{\circ} \mathrm{C}\right)$ that completely damaged the young kiwi shoots. Thus, in 2011, there was no fruit yield. The winters of 2012/13 took a very different course. The lowest daily temperature did not drop below $-15^{\circ} \mathrm{C}$, but the winter was hard because it was long (till early April). The winters of 2013/14 and 2014/15 were mild and quite short. The summer of 2015 experienced a long and extremely hard drought from the end of July till early October.

The analysis of the results included: mean fruit yields from the plants for each year, and an analysis of the total yield amount divided into total yield (whole fruit from the plant) and commercial yield (fruit left after the small - less than $10 \mathrm{~mm}$ diameter, misshapen or damaged fruit was sorted out). Fruit was picked once for each cultivar, and separately for each vine. Date of harvesting was determined annually. An organoleptic determination was done when the first fruit on the vine was ripe and ready to eat (fruits were soft and sweet, sugar content in brix scale was measured by pocket refractometer Pal-1, Atago, Japan). In the last year of the experiment a leaf samples for control mineral composition were collected. At the end of August 2015, leaf samples were taken from the middle part of the this year's long vegetative shoots. Than samples were oven-dried at $70^{\circ} \mathrm{C}$ and treated with the mixture of $\mathrm{HNO}_{3}$ and $\mathrm{HClO}_{4}$. Atomic absorption spectrophotometry was used to measure the $\mathrm{K}, \mathrm{Mg}$, and $\mathrm{Ca}$ concentrations. Phosphorus was determined calorimetrically, and $\mathrm{N}$ was determined using the Kjeldahl method. The experiment was done in a randomised block design with 4 replicates, and with 5 plants per replicate. The data were analysed statistically with ANOVA. To establish the significance of differences between the means, the Duncan's Multiple Range Test was used. 


\section{RESULTS AND DISCUSSION}

From 2010 to 2015, the fruit harvest of the hardy kiwi cultivars took place between 20 September and 15 October. The harvest time was conditioned by special cultivar features, and the weather course for each year. The earliest time of fruit harvesting was noted for the 'Geneva' cultivar; mostly from 20-25 September. The latest fruit harvesting time was for the 'Weiki' cultivar; with a harvesting time mainly from 10-15 October. The results presented in Table 1 and 2 show that in the subsequent years (2010-2015) fruit yield increased for both the mulched and herbicide treated vines. The highest total amount of fruit yield for 2010-2015 was noted for the mulched vines rather than the herbicide-treated vines. Cultivars 'Ananasnaya' and 'Geneva' had exceptionally high yields of fruit. In the 5 subsequent years of the study, $33.8 \mathrm{~kg}$ and $30.1 \mathrm{~kg}$ per vine were harvested, respectively, from mulched plants, and 24.7 and $21.2 \mathrm{~kg}$ per vine, respectively, from herbicide-treated plants. The least fertile was the cultivar 'Ken's Red'. The yields of this cultivar did not increase significantly from one year to another (Table 1 and 2).

Table 1. Mean total fruit yielding of 5 hardy kiwifruit cultivars grown under straw mulching (kg/plant) Tabela 1. Średni całkowity plon owoców 5 odmian aktinidii ściółkowanej słomą (kg/roślinę)

\begin{tabular}{lllllll}
\hline $\begin{array}{l}\text { Cultivar } \\
\text { Odmiana }\end{array}$ & 2010 & 2012 & 2013 & 2014 & 2015 & $\begin{array}{c}\text { Total } \\
\text { Razem }\end{array}$ \\
\hline 'Ananasnaya' & $5.42 \mathrm{c}$ & $6.83 \mathrm{~d}$ & $7.17 \mathrm{~d}$ & $7.06 \mathrm{c}$ & $7.30 \mathrm{~d}$ & $33.8 \mathrm{c}$ \\
\hline 'Geneva' & $3.93 \mathrm{~b}$ & $5.35 \mathrm{c}$ & $6.55 \mathrm{c}$ & $6.92 \mathrm{c}$ & $7.35 \mathrm{~d}$ & $30.1 \mathrm{c}$ \\
\hline 'Jumbo' & $2.75 \mathrm{a}$ & $3.16 \mathrm{a}$ & $4.80 \mathrm{~b}$ & $5.66 \mathrm{~b}$ & $4.82 \mathrm{c}$ & $21.2 \mathrm{ab}$ \\
\hline 'Ken's Red' & $3.25 \mathrm{ab}$ & $2.91 \mathrm{a}$ & $3.82 \mathrm{a}$ & $3.92 \mathrm{a}$ & $3.28 \mathrm{a}$ & $17.2 \mathrm{a}$ \\
\hline 'Weiki' & $2.92 \mathrm{a}$ & $4.35 \mathrm{~b}$ & $4.85 \mathrm{~b}$ & $5.94 \mathrm{~b}$ & $6.25 \mathrm{~b}$ & $24.3 \mathrm{~b}$ \\
\hline
\end{tabular}

Means in the column sign by the same letter, do not differ significantly according to Duncan's Multiple Range Test at $p=0.05$.

Średnie w obrębie kolumn oznaczone tą samą literą nie różnią się istotnie, według testu Duncana, przy poziomie istotności $p=0,05$.

Table 2. Total fruit yielding of 5 hardy kiwifruit cultivars grown with the use of herbicides ( $\mathrm{kg} / \mathrm{plant})$ Tabela 2. Średni całkowity plon owoców 5 odmian aktinidii uprawianych na ugorze herbicydowym (kg/roślinę)

\begin{tabular}{llllllc}
\hline $\begin{array}{l}\text { Cultivar } \\
\text { Odmiana }\end{array}$ & 2010 & 2012 & 2013 & 2014 & 2015 & $\begin{array}{c}\text { Total } \\
\text { Razem }\end{array}$ \\
\hline 'Ananasnaya' & $4.75 \mathrm{c}$ & $4.92 \mathrm{~d}$ & $5.10 \mathrm{c}$ & $5.25 \mathrm{c}$ & $4.72 \mathrm{c}$ & $24.7 \mathrm{~d}$ \\
\hline 'Geneva' & $3.22 \mathrm{~b}$ & $3.54 \mathrm{c}$ & $4.86 \mathrm{c}$ & $4.72 \mathrm{c}$ & $4.84 \mathrm{c}$ & $21.2 \mathrm{~d}$ \\
\hline 'Jumbo' & $1.43 \mathrm{a}$ & $2.12 \mathrm{ab}$ & $3.51 \mathrm{~b}$ & $3.33 \mathrm{~b}$ & $3.10 \mathrm{~b}$ & $13.5 \mathrm{~b}$ \\
\hline 'Ken's Red' & $1.54 \mathrm{a}$ & $1.82 \mathrm{a}$ & $2.24 \mathrm{a}$ & $2.52 \mathrm{a}$ & $1.94 \mathrm{a}$ & $10.1 \mathrm{a}$ \\
\hline 'Weiki' & $1.72 \mathrm{a}$ & $2.93 \mathrm{~b}$ & $3.84 \mathrm{~b}$ & $4.75 \mathrm{c}$ & $4.66 \mathrm{c}$ & $17.9 \mathrm{c}$ \\
\hline
\end{tabular}

Explanation see Table 1 - Objaśnienia patrz tab. 1.

Fruiting of the mulched vines improved in all of the tested kiwi cultivars already after the first 2010 season. In 2010, the average fruit yield was $1.12 \mathrm{~kg}$ higher than the control. 'Ken's Red' $(1.71 \mathrm{~kg})$ and 'Weiki' $(1.20 \mathrm{~kg})$ showed the biggest differences in fruiting. In 2011 and 2012 , of the experiment the differences in the fruit yielding of the mulched vines compared to the control, was more than $1 \mathrm{~kg}$ for all cultivars. In the case of the most fertile cultivars, like 
'Ananasnaya' and 'Geneva', the differences were 1.81 and $2.20 \mathrm{~kg}$ per vine, respectively, and the mulched plants benefitted the most. Such a fruit-harvest increase from one plant, certainly must give a higher total yield per unit area and a higher income. The use of straw mulching was very beneficial in the last year of the study (2015) when there was a severe drought from extreme heat, which started at the end of July. Compared to the results from 2014, it should be noted that the 2015 fruit yield, even though there was a drought, was not reduced for the mulched plants. For the control vines treated by herbicide, the 2015 fruit yield on all cultivars, except 'Weiki', decreased. According to the earlier provided scientific works, and also by other authors, mulched kiwi plants which were not provided with additional watering, yielded slightly less that plants in watered fields (Latocha 2015; Marosz 2016). It is widely confirmed that plants mulched with different organic matter, had a better root system development in the upper layer of the soil and a better nutrient and water uptake. Such results were observed on highbush blueberry (Wach 2004), apple trees (Wrona 2008), and strawberry plants (Kęsik and Maskaleniec 2004). The use of orchard soil-maintenance methods has shown significant effects on the horizontal and vertical root arrangement. Thus, the result is better nutrient uptake and better fruiting (Wrona 2008).

In the second year of the experiment (2011), severe ground-frost occurred and caused strong growth reduction of all plants. In this year there was any fruit on the plants. Such hard spring frosts were noted also in other parts of the country and destroyed new growth of many plants (Jerzak 2011). The condition of hardy kiwifruit plants in the spring 2011 was probably additionally decreased by weather course during previous winters 2009/10 and 2010/11. This winters were quite warm and short, thus Actinidia started to grow early. Similar condition were in the spring 2017, when Actinidia was no fruiting without protection. In such case spring frost protection of commercial orchard is extremely required. In the whole experiment it cannot be excluded, that some light damage of spring frosts occurred in other years of the study than 2011, but they were not detectable during visual assessment. They could, however, slightly affected the yield of fruits.

A higher commercial yield of hardy kiwifruit was recorded on mulched plants in the last year of the experiment, on the cultivars 'Ananasnaya', Geneva', and 'Weiki'. The harvest was $6.83,6.08$, and $5.94 \mathrm{~kg}$ of fruit per vine, respectively. The highest commercial yield was also noted on these cultivars in the control plots. However, the mean commercial yield was lower: $4.85,4.65$, and 4.19 , respectively (Table 3 and 4).

Table 3. Mean trade fruit yielding of 5 hardy kiwifruit cultivars grown under straw mulching (kg/plant) Tabela 3. Plon handlowy 5 odmian aktinidii ściółkowanej słomą (kg/roślinę)

\begin{tabular}{lllllll}
\hline $\begin{array}{l}\text { Cultivar } \\
\text { Odmiana }\end{array}$ & 2010 & 2012 & 2013 & 2014 & 2015 & $\begin{array}{c}\text { Total } \\
\text { Razem }\end{array}$ \\
\hline 'Ananasnaya' & $5.15 \mathrm{c}$ & $6.49 \mathrm{~d}$ & $6.81 \mathrm{c}$ & $6.60 \mathrm{c}$ & $6.83 \mathrm{~d}$ & $31.9 \mathrm{e}$ \\
\hline 'Geneva' & $3.73 \mathrm{~b}$ & $5.08 \mathrm{~s}$ & $6.22 \mathrm{c}$ & $6.23 \mathrm{c}$ & $6.08 \mathrm{c}$ & $27.3 \mathrm{~d}$ \\
\hline 'Jumbo' & $2.61 \mathrm{a}$ & $3.00 \mathrm{a}$ & $4.56 \mathrm{~b}$ & $5.17 \mathrm{~b}$ & $4.57 \mathrm{~b}$ & $19.9 \mathrm{~b}$ \\
\hline 'Ken's Red' & $2.98 \mathrm{a}$ & $2.66 \mathrm{a}$ & $3.32 \mathrm{a}$ & $3.62 \mathrm{a}$ & $3.07 \mathrm{a}$ & $15.6 \mathrm{a}$ \\
\hline 'Weiki' & $2.77 \mathrm{a}$ & $4.13 \mathrm{~b}$ & $4.60 \mathrm{~b}$ & $5.64 \mathrm{~b}$ & $5.94 \mathrm{c}$ & $23.1 \mathrm{c}$ \\
\hline
\end{tabular}

Explanation see Table 1 - Objaśnienia patrz tab. 1. 
Table 4. Mean trade fruit yielding of 5 hardy kiwifruit cultivars grown with the use of herbicides (kg/plant) Tabela 4. Plon handlowy 5 odmian aktinidii uprawianych na ugorze herbicydowym (kg/roślinę)

\begin{tabular}{llllllc}
\hline $\begin{array}{l}\text { Cultivar } \\
\text { Odmiana }\end{array}$ & 2010 & 2012 & 2013 & 2014 & 2015 & $\begin{array}{c}\text { Total } \\
\text { Razem }\end{array}$ \\
\hline 'Ananasnaya' & $4.27 \mathrm{c}$ & $4.63 \mathrm{c}$ & $4.89 \mathrm{c}$ & $4.92 \mathrm{c}$ & $4.85 \mathrm{c}$ & $23.6 \mathrm{~d}$ \\
\hline 'Geneva' & $2.90 \mathrm{~b}$ & $3.19 \mathrm{~b}$ & $4.37 \mathrm{c}$ & $4.50 \mathrm{c}$ & $4.65 \mathrm{c}$ & $19.8 \mathrm{~d}$ \\
\hline 'Jumbo' & $1.19 \mathrm{a}$ & $1.51 \mathrm{a}$ & $3.16 \mathrm{~b}$ & $3.48 \mathrm{~b}$ & $2.79 \mathrm{~b}$ & $12.1 \mathrm{~b}$ \\
\hline 'Ken's Red' & $1.61 \mathrm{ab}$ & $1.64 \mathrm{a}$ & $2.02 \mathrm{a}$ & $2.27 \mathrm{a}$ & $1.74 \mathrm{a}$ & $8.90 \mathrm{a}$ \\
\hline 'Weiki' & $1.55 \mathrm{ab}$ & $2.64 \mathrm{~b}$ & $3.45 \mathrm{~b}$ & $4.27 \mathrm{c}$ & $4.19 \mathrm{c}$ & $16.1 \mathrm{c}$ \\
\hline
\end{tabular}

Explanation see Table 1 - Objaśnienia patrz tab. 1.

A good yielding for some other hybrids of hardy kiwi was earlier supported by Bieniek (2012) were mean total yield for cultivar 'Purpurowaja Sadowaja' reached $10.1 \mathrm{~kg}$ per plant. Generally, the commercial yield of mulched plants compared to the control was higher; from $0.83 \mathrm{~kg}$ to $1.98 \mathrm{~kg}$, depending on the cultivar and the year (Table 5).

Table 5. The differences in trade yielding of 5 hardy kiwifruit cultivars mulched with straw or grown with the use of herbicides

Tabela 5. Różnica w plonie handlowym 5 odmian aktinidii ściółkowanych słomą i uprawianych na ugorze herbicydowym (kg/roślinę)

\begin{tabular}{lcccccc}
\hline $\begin{array}{l}\text { Cultivar } \\
\text { Odmiana }\end{array}$ & 2010 & 2012 & 2013 & 2014 & 2015 & $\begin{array}{c}\text { Total } \\
\text { Razem }\end{array}$ \\
\hline 'Ananasnaya' & $0.88 \mathrm{a}$ & $1.86 \mathrm{c}$ & $1.92 \mathrm{~b}$ & $1.68 \mathrm{~b}$ & $1.98 \mathrm{~b}$ & $8.3 \mathrm{c}$ \\
\hline 'Geneva' & $0.83 \mathrm{a}$ & $1.89 \mathrm{c}$ & $1.85 \mathrm{~b}$ & $1.43 \mathrm{ab}$ & $1.43 \mathrm{ab}$ & $7.5 \mathrm{~b}$ \\
\hline 'Jumbo' & $1.42 \mathrm{~b}$ & $1.49 \mathrm{~b}$ & $1.40 \mathrm{ab}$ & $1.78 \mathrm{~b}$ & $1.78 \mathrm{~b}$ & $7.8 \mathrm{~b}$ \\
\hline 'Ken's Red' & $1.37 \mathrm{~b}$ & $1.02 \mathrm{a}$ & $1.30 \mathrm{a}$ & $1.33 \mathrm{a}$ & $1.33 \mathrm{a}$ & $6.4 \mathrm{a}$ \\
\hline 'Weiki' & $1.22 \mathrm{~b}$ & $1.49 \mathrm{~b}$ & $1.15 \mathrm{a}$ & $1.37 \mathrm{~b}$ & $1.75 \mathrm{~b}$ & $7.0 \mathrm{a}$ \\
\hline
\end{tabular}

Explanation see Table 1 - Objaśnienia patrz tab. 1.

The highest commercial yield was typical for the most fertile cultivars, such as 'Ananasnaya', 'Geneva', and 'Weiki' - both for mulched and herbicide-treated vines. The total amount of commercial fruit yield in this experiment for the cultivar 'Ananasnaya', mulched by straw, was $31.9 \mathrm{~kg}$, and was lower $1.90 \mathrm{~kg}$ than the total fruit harvest. For the control plants, the total amount of the commercial fruit yield was $23.5 \mathrm{~kg}$, and was lower $1.18 \mathrm{~kg}$ than the total fruit harvest. The second best fruiting cultivar, 'Geneva', had similar results. It may be conclude, that the beneficial fruit yielding of mulched plants provide a much higher income. Assuming that the wholesale price for mini kiwi fruit is 10 PLN per $1 \mathrm{~kg}$ and 1168 vines per 1 hectare (Marosz 2016), we can get a higher gross margin for mulched 'Ananasnaya' and 'Geneva' plants at 23126 PLN and 16692 PLN, respectively. This is a big difference that economically justifies the need for a straw purchase, and outweighs the labour cost as well. Better yielding of mulched kiwi in the experiment, was possible not only because of a better soil humidity attainment but also due to the humus and nutrient-enriched upper soil layer. Mulch from organic compounds that decay quite fast (e.g. straw) enrich soil with some macronutrients. This was confirmed earlier by Kęsik and Maskalaniec (2004) for strawberries. They also observed less nitrogen content in the leaves when dust was used for mulching, whereas using straw had no such effect. These results partly explain the better yielding of mulched kiwi in the presented study. The macroelement content in the leaves of kiwi, was not affected by straw mulching (Table 6). 
Table 6. Macroelement leaf content of hardy kiwifruit cultivars grown with the use of herbicides or straw mulching (in \% of dry weight)

Tabela 6. Zawartość makroskładników w liściach odmian aktinidii ściółkowanych słomą i uprawianych na ugorze herbicydowym (\% suchej masy)

\begin{tabular}{lllcccc}
\hline Treatment & $\begin{array}{c}\text { Cultivar } \\
\text { Odmiana }\end{array}$ & $\mathrm{N}$ & $\mathrm{P}$ & $\mathrm{K}$ & $\mathrm{Mg}$ & $\mathrm{Ca}$ \\
\hline \multirow{2}{*}{$\begin{array}{l}\text { Herbicide } \\
\text { Ugór herbicydowy }\end{array}$} & 'Ananasnaya' & $3.65 \mathrm{a}$ & $0.34 \mathrm{a}$ & $1.15 \mathrm{a}$ & $0.19 \mathrm{a}$ & $1.52 \mathrm{a}$ \\
\cline { 2 - 7 } & 'Geneva' & $3.74 \mathrm{a}$ & $0.32 \mathrm{a}$ & $1.03 \mathrm{a}$ & $0.17 \mathrm{a}$ & $1.63 \mathrm{a}$ \\
\cline { 2 - 7 } Straw mulching & 'Jumbo' & $3.52 \mathrm{a}$ & $0.29 \mathrm{a}$ & $1.12 \mathrm{a}$ & $0,17 \mathrm{a}$ & $1.55 \mathrm{a}$ \\
\hline \multirow{2}{*}{ Sciółkowanie słomą } & 'Ananasnaya' & $3.68 \mathrm{a}$ & $0.31 \mathrm{a}$ & $1.13 \mathrm{a}$ & $0.21 \mathrm{a}$ & $1.58 \mathrm{a}$ \\
\cline { 2 - 7 } & 'Geneva' & $3.58 \mathrm{a}$ & $0.27 \mathrm{a}$ & $1.17 \mathrm{a}$ & $0.19 \mathrm{a}$ & $1.55 \mathrm{a}$ \\
\cline { 2 - 7 } & 'Jumbo' & $3.54 \mathrm{a}$ & $0.28 \mathrm{a}$ & $1.09 \mathrm{a}$ & $0.18 \mathrm{a}$ & $1.51 \mathrm{a}$ \\
\hline
\end{tabular}

Explanation see Table 1 - Objaśnienia patrz tab. 1.

Although these measurements were provided only in the last year of the experiment, the results confirm the earlier findings of Kęsik and Maskaleniec (2004). However, in the work of Sas-Paszt et al. (2014) any mulches applied to apple trees cv. 'Gold Millenium' did not affect significantly the tree growth and did not have positive effect on the total soluble solids of the fruit. Although Kotze et al. (2015) proved that yield of mulched apple trees generally was higher in the lighter then heavier site. Very good growth of ornamental shrubs in containers, was also achieved when cut-rye straw was used for mulching, however in some species and cultivars vegetative growth reduction was also observed (Marosz 2012). Although there was no such statistical observation provided, it should be mentioned that mulching was a very effective weed control in this kiwi-cultivation experiment.

\section{RECAPITULATION}

The results of this experiment demonstrated that straw used as soil mulching on five cultivars of hardy kiwi planted in sandy loam soil, significantly improved fruit yielding every year of the study. Soil mulching improved fruit yield and occurred favourably in the years with low precipitation. Soil mulching could help to maintain a higher fruit yield than the fruit yield of non-mulched, herbicide-treated vines. Straw mulching did not negatively affect macroelement uptake and concentration, in the leaves. Soil mulching provides good weed control and does so without the need for herbicides. A mulching treatment seems to be helpful when setting up a field in which there is no additional irrigation. It could allow kiwi field far away from the farm, where watering installation is difficult to do. On the other hand, overhead sprinkles irrigation protecting before late spring frost on the commercial kiwiberry orchards is required.

\section{REFERENCES}

Bieniek A. 2012. Yield, morphology and biological value of fruits of Actinicie arguta and Actinidia pupurea and some of their hybrid cultivars grown in the north-eastern Poland. Acta Sci. Pol., Hortorum Cultus 11(3), 117-130.

Chesoniene L. 2000. Comparsion of some biological features and potential od Actinidia kolomicta cultivars. Acta Hortic. 538, 769-774. 
Ferrini F., Fini A., Frangi P., Amoroso G. 2008. Mulching of ornamental tree: effects on growth and physiology. Arboricult. Urban Forestry 34, 157-162.

Harris R.W., Clark J.R., Matheny N.P. 2004. Arboriculture. Integrated management of landscape trees, shrubs and vines. 4th ed. New Jersey, Pearson Education, Inc, 07458.

Jerzak E. 2011. Rekordowe majowe przymrozki w 2011 r i ich wpływ na drzewa i krzewy Ogrodu Botanicznego w Poznaniu [Record frosts in May 2011, and their effect on trees and shrubs at the Botanic Garden in Poznań]. Rocz. Pol. Tow. Dendrol. 59, 37-61. [in Polish]

Kęsik T., Maskaleniec T. 2004. Wpływ ściółkowania na zawartość składników mineralnych w glebie i w liściach truskawki [Effect of soli mulching on nutrients content in soil and strawberry leaves]. Rocz. AR Pozn., Ogrodnictwo 356(37), 87-93. [in Polish]

Kotze W.P., Van der Merwe J.D.P., Nicholson A.F., Taylor N.J., Schmeisser M., Lötze E. 2015. Changes in phosphorus status of 'Crips 'Pink' apple trees after application of mulches, https://repository.up.ac.za/bitstream/handle/2263/49698/Kotze_Changes_2015.pdf?sequence=1, access: 18.12.2017.

Laszlovszky Zmarlicka A. 2015. Wpływ ściółkowania gleby na owocowanie borówki brusznicy [The influance of soil mulching on yielding of ligonberries]. Zesz. Nauk. Inst. Ogrod. 23, 35-40. [in Polish]

Latocha P., Krupa T. 2007. Morphological, chemical and sensory analysis of promising genotypes of hardy kiwifruit (Actinidia Lindl.) obtained in the breeding programme at UWLS. Ann. Wars. Univ. Life Sci. - SGGW, Horticulture and Landscape Architecture 28, 111-119.

Latocha P. 2012. Some morphological and biological features of 'Bingo' - a new hardy kiwifruit cultivar from Warsaw University of Life Sciences (WULS) in Poland. Rocz. Dendrol. 60, 61-67.

Latocha P. 2015. Możliwości towarowej produkcji owoców aktinidii - mini kiwi, w: Czynniki wpływające na plonowanie i jakość roślin sadowniczych. Red. K. Tomala. Warszawa, Wydaw. BASF Sp. z o.o., 31-44. ISBN 978-83-64729-05-8. [in Polish]

Latocha P. 2017. The nutritional and health benefits of kiwiberry (Actinidia arguta). A review. Plant Foods Human Nutrit. 72(4), 325-334.

Marosz A. 2009. Winterhardiness and growth of Actinidia arguta and A. kolomikta cultivars in central Poland. Acta Agrobot. 62, 179-188.

Marosz A. 2012. Ocena różnych sposobów ściółkowania podłoża w uprawie krzewów ozdobnych w pojemnikach [Efficiency of sevelal mulches material used for container grown shrubs]. Zesz. Nauk. Inst. Sadow. Kwiac. 20, 61-68. [in Polish]

Marosz A. 2016. Rachunek ekonomiczny produkcji owoców aktinidii ostrolistnej nowej rośliny sadowniczej w dwóch systemach uprawy [The profitability calcus of hardy kiwifruit production a new pomology plant in two growing system]. Folia Pomer. Univ. Technol. Stetin., Oeconomica 329, 85-94. [in Polish]

Sas-Paszt L., Pruski K., Żurawicz, E., Sumorok B., Derkowska E., Głuszek S. 2014. The effect of organic mulches and mycorrhizal substrate on growth, yield and quality of Gold Milenium apples on M.9 rootstock. Canadian J. Plant Sci. 94, 281-291.

Szewczuk A., Dereń D., Gudarowska E. 2011. Ocena wzrostu drzew jabłoni prowadzonych w redlinach przy zastosowaniu nawadniania i ściółkowania gleby [The estimation of growth of trees planted in ridges with irrigation and soil mulching]. Infrastruk. Ekol. Ter. Wiej. 5, 71-81. [in Polish]

Wach D. 2004. Rozmieszczenie korzeni borówki wysokiej i zawartości składników w profilu glebowym [Root distribution of haighblus blueberry and nutrient content on soil profile]. Rocz. AR Pozn., Ogrodnictwo 356(37), 217-224. [in Polish]

Williams M.A., Boyd L.M., McNeilage M.A., Macrae E.A., Ferguson A.R. 2003. Development and commercialization of „Baby Kiwi” (Actinidia arguta Planch.). Acta Hortic. 610, 81-86 .

Wrona D. 2008. Pogląd na nawożenie jabłoni azotem w sadach intensywnych, w: Czynniki wpływające na plonowanie i jakość owoców roślin sadowniczych. Materiały konferencyjne, Warszawa 11-12 stycznia 2008, [b.w.], 131-142. [in Polish] 
Abstract. Kiwiberry, or hardy kiwifruit (Actinidia arguta) is a new pomological plant in Poland. There are many possibilities for setting up an orchard with this species. However, Actinidia is susceptible to late spring frost. Summer irrigation for good fruit yielding is required. In this experiment the effect of soil mulching on the yielding of five cultivars of hardy kiwi fruit was observed. The orchard was started in 2005, but the experiment was conducted from 2010-2015, when plants were full fruiting. Half of the line of each cultivar was mulched with straw, the other half was treated with an herbicide. No additional summer irrigation was provided. Yielding of actinidia cultivars was very varied, but the results showed that straw soil mulching improved the fruit yield of all cultivars. The highest total and commercial yield was recorded for the cultivars: 'Ananasnaya', 'Geneva', and 'Weiki'. Generally, the commercial yield of plants mulched with straw was higher; from 0.83 to $1.98 \mathrm{~kg}$ per plant compared to the control which had herbicide stripes along the rows. 
